\title{
Challenges Facing the Master Plans of the Cities and Contemporary Forms in Urban Planning

\author{
Dr. BUSHRA ABDULRAHIM YASS
}

Civil Engineer- M.Sc. Urban and Regional Planning

Ph.D. Philosophy in Urban and Regional Planning/Urban Development

\begin{abstract}
The master plan and the zoning emanating from it which had been found in every part of the world in $20^{\text {th }}$ century faced many problems because of various and different issues related to the city led to appear another forms of urban planning according to the social and economic rapid increasing, like urban management and strategic planningthat is what the research discusses. Research aims to clarify that the master plan has an important role in directing and organizing the city growth and its expansion and organizing the functional relationships between the urban gatherings so in order to play this important role, research puts a methodology to overcome all the problems and challenges which affect the work mechanisms of the master plan to keep pace the social,economi,environmental and urban changes in order to support the city development and improving the life of residents and to prevent the illegal development.
\end{abstract}

\section{Introduction}

The urban planning process is one of the most important urban operationswhich is directly related to humans as well as land use and the final product of these processes is the master planwhich is called by some the spatialplan association with the place and its effectiveness in encounter of urban growth of cities.

\section{1- The master Plan}

It is the basic document, which held under legal responsibility who overtakes and abuses the urban irregularities.[1] p. 43

The master plan characterized byacomprehension and the long of term, it is responsible of covering all the current and future populationneeds. [2]

\section{1-1 Functions of the master plan}

The most important functions of the master plans are:

1- Developing a model for the planned unit neighborhood in order to achieve social integration.

2-Preparing a long term plan through predicting of population size and economic and social future changes, a plan from which to sketch a futuristic picture of a city and the society in which they live. [3] p. 25-27 


\section{1-2 Challenges faced by the master plan}

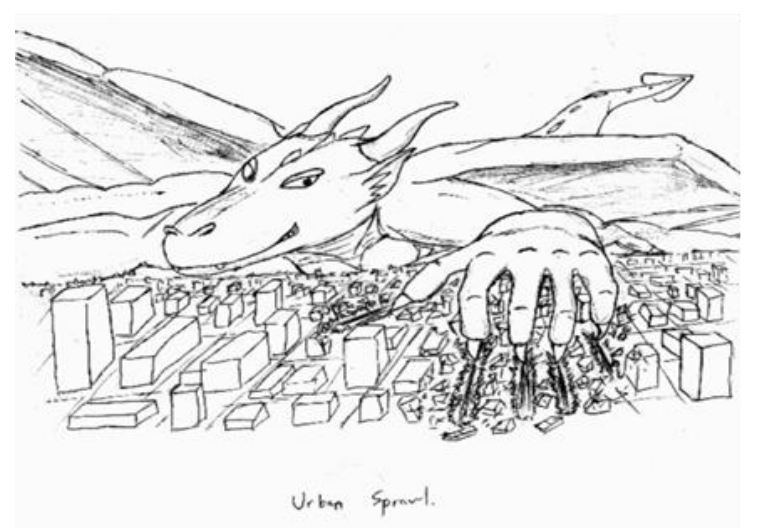

The hypotheses developed by themaster planaresometimes unstable because of the challenges faced by the plan such as:

1-The urban sprawl, sprawl is the spread of urban areas and the destruction of open space, and it is ultimate outward extension into undeveloped areas, low density, and leap frog development, and segregation of housing and commercial development. [4] Chapter 2 p. 12

2- Economic growth.

3- Pressures of globalization.

4-The role of local governments and the increased validity of them.

5- Using cars and development of transportation.[3]

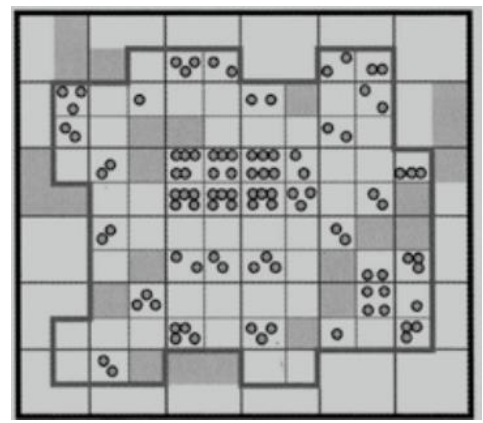

Fig.1 Leap Frogging development[5] p. 10

6- Developed in communications have always involved urban concentrations.

Communication technology allowing both distribution and command and control functions to take place with the same urban place. [6] chapter 9, p. 160

\section{1-3 Negatives that accompany themaster plan}

1- Oftenthe master plans exceed the time of duration assigned to them before they go into effect because they take a long time to prepare not compatible with the rapid urban growthwhich requires the provision of housing, infrastructure and employment opportunities for new residents.

2-Most of the master plans have not kept pace of economic, social and urban changes, which always requires a reconsideration. 
3- Failure to deal with population growth, which often more than the capacity of the citythen an interaction of the functional relationships is produced which affects the value of the land,this requires ongoing treatments and by various methods[7] p.1,As in Damascus experience where the expectations of the population factor bucked reality in terms of growth rates and its trends, urban areas have expanded outside the administrative boundaries and the nearby villages forms a belt around it resulted in the erosion of Ghouta arearenowned of agriculture [8] p.79

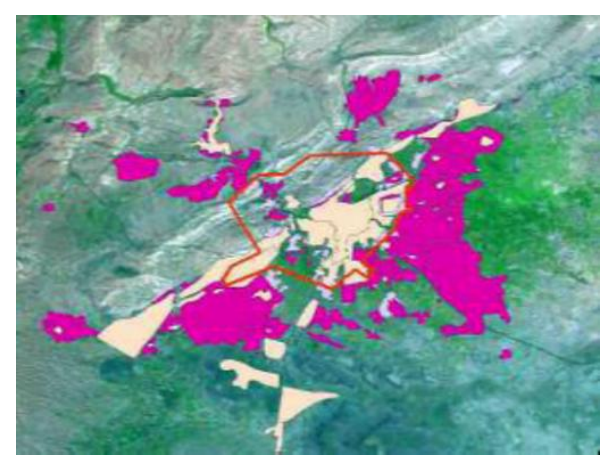

Fig.2 Trends in the expansion of the city of Damascus 1990-2005

At the expense of Lands of Ghouta eastward[9] p.6

4- Affecting the value of the land,affects the movement of investment in housingfield alsowhich is a part of the policies development to achieve the economic advancement and to improve the social and housing environment, especially if it was withina legal and legislative environmentAttracts investors and boost their confidence in government institutions.[10]P.128

5- Zoning emanating from the master plan does not reflect the reality of the urban and rural areas and dos not deal with social and environmental problems in the critical peri-urban areas and urbanizing rural areas.

6- There is a correlation between the environmental urban management and the spatial urban policiesembodied in the plans so the absence of a successful urban environmental management caused failure to achieve coherence between the preservation of the natural social environment and these spatial urban policies. [11] P.33

7- If there is not a rational deal with the drawbacks mentioned above, the master planworks as a contributor to the non-official development specially the long term plan. [12] P.7

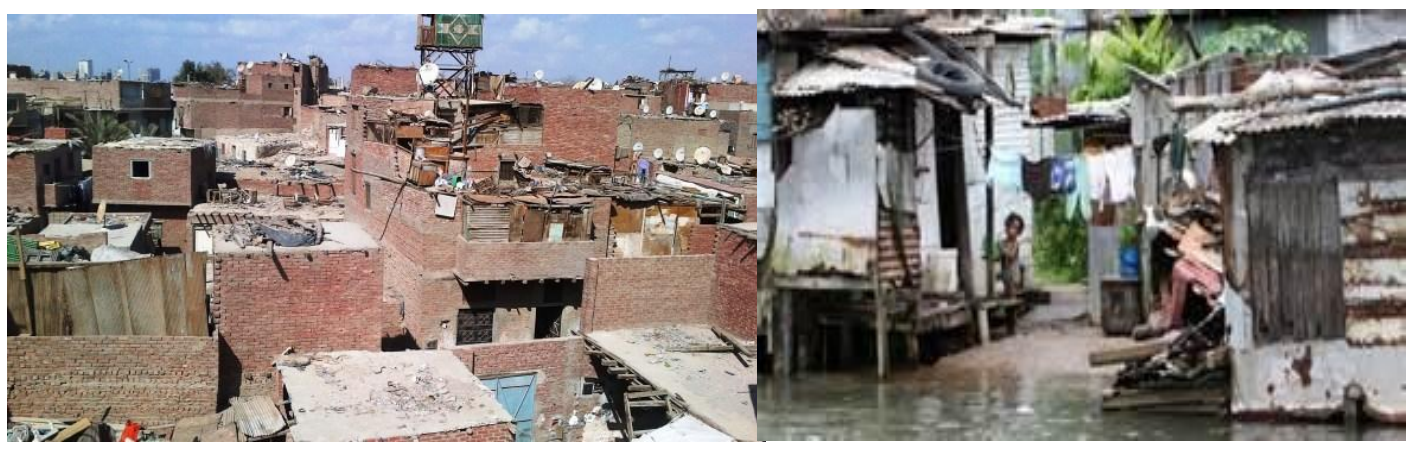

Fig.3 Consequences of unchecked development 
8- The plans lacksto the principle of consistency and integration between the city and surrounding.[9] p. 284. The principle of consistency and integration included of:

1- The spatial distance between urban gathering in the cityand measured by the law of gravity and appreciate the importance of these gatherings by the distance between them.

2- The time required to cut the distances between these urban gatherings whenever they diverged from each, weakened functional relationships which combined them.[13]P.555

9- Late introduced services until the last touches of plan be finished, is a cover for carelessness of the local governments. [14], chap.3 p.9

\section{2-Contemporary forms in urban planning:}

Because of the challenges facing the base scenario,new forms of urban planning have emerged in response to environmental, economic and social changes and some of these forms:

\section{2-1 Urban Management}

It is a new style of the city's development in the global southled by a number of institutions such as the World Bank and UN agencies,It contrasts with the urban planning controlled by government.

\section{2-2 Strategic Planning}

It includes strategic spatial planning, long-term spatial plan, wide planwith local plans and projects. The plan does not deal with all parts of the city because it is a strategic means focus only on the important aspects of the overall goals of the plan.There is a shift toward other forms of planning such, Structural plan, Strategic plan, strategic growth plans. [3], p.27,So strategic planning is the art of science of integrated planning for Community and institutions, it includes strategic thinking, administration's strategy and based on tangible reality, based onavailable financial allocation andrequiresImmediate and futurework mechanisms to employ them in the development and improving the performance of the organization for the better.

\section{3- The difference between the strategic planning and traditional planning}

Strategic planning is different from the traditional planning includes:

1- The action planning: It is the application of the planning processactuallywhichemanating fromthe existing situationin the field and which is working out according to the available potential.

\section{2- The participation}

It is the planning process exercised with the participation of civil society organizations and representatives of the local community and levels of administration.

\section{4- Conclusions}

Based on what had been mentioned above, the research reached to a set of conclusions and results: 
1- The longest comprehensive plan in the preparation plays the most role in the occurrence of informal development.

2- Population projections factor is one of the key components of the master plan.

3- Population projections factor is one of the key components of the master plan.

4- The master plans are not fixed and not permanent but change depending on the situation, ata specified period of time has changed and enters another case.

5- Master plans play an important role in regulating the relationship between the city and its surrounding.

6- Lack of plan to the principle of consistency and integration between the city and its surroundings, leading to weakness of the functional relationship between urban gatherings.

7- Neglecting the economic factor in the master plan affects the value of land and the heightenedthe competition between land uses.

\section{5- Recommendations}

The master plan has an important role in guiding the growth and expansion of the city and enhancing the functional relationships between the urban communities so in order to play this role and overcomes the problems and face the challenges, research displays some recommendations below:

1- Taking into account that themaster plans enhance the various functional relationships.

2- Master plan must be based on the accurate official statistics and seized future expectations.

3- Conducting continuous assessment and review of the plans to align and keep pace with social and economic changes.

4- Development the departments responsible for urban planning and

Policy development.

5- Making Policy and action that stops the rapid urbanization towards of the surroundings.

6- Adoption thescientific economiclogic as a basic for predictingthe growth of the city and studying of land use accurately.

7-To achieve coherence between the preservation of the natural social environment and spatial urban policiesembodied in the plansthere must be a successful urban management.

8- Effective plan is necessary in which concepts of sustainability effectiveness, flexibility, clarity to people.

\section{References}

[1]Yass, BushraAbdulRahim "AN ANALYTICAL STUDY OF THE EXPANSION OF SULAYMANIAH CITY AND URBANIZING NEARBY VILLAGES “ ATHESIS SUBMITTED TO CENTER OF URBAN \& REGIONAL PLANNING FOR POST GRADUATE STUDIES- UNIVERSITY OF BAGHDAD IN PARTIAL FUL FILLMENT 
OF THE REQUIREMENTS OF THE Ph. D. DEGREE OF PHILOSOPHY IN URBAN AND REGIONAL PLANNING , 2015

[2]Stein, Jay, M.” Classic Reading in Urban Planning and Introduction" Mc Grew-Hill.Inc. USA-1995,

[3]Madbouly,Dr. Mustafa, "Revising urban Planning in the Middle East North Africa Region", Regional Study prepared for: Revising Urban Planning, Global Report Human Settlement 2009.

[4]Robert W., Bunchell, Anthony Downs, Barbara MeCann and SahanMukhergi, Book" Sprawl Costs", Island Press-Washington. Covelo. London, 2005

[5]ElinaBesussi, Nancy Chin, Michael Batty and Paul Longly, university of College London, chapter2, 2010

[6] Simon Parker, Book "The urban experience "Encountering the city Routlege, published Taylor and Francis group - London \& New York 2004

[7]Al-Kenani,KadimBasheer, research "The city of Baghdad - Analysis of Economic Mechanisms Act in the Upbringing and Development" “ مدينتبذاد"journal of the planner and development - Number nineteenth2008 [Translated from Arabic]

[8]Jabbour, Saadallah, research "Urban happenings in Damascus and organizing plan(1965 to 1985), " الدجريات العمر انية بدمثق و المخطط التنظيمي العام للفترة 1985-1995 Faculty of Architecture, University of Damascus, Damascus University Journal - Volume VII XI. Second Issue 2001 [translated from Arabic]

[9]Al-Dajani, Deena \&Abdeen Mohammed Yessar research" "The best future trends for the expansion of the city of Damascus with the help of geographic information systems

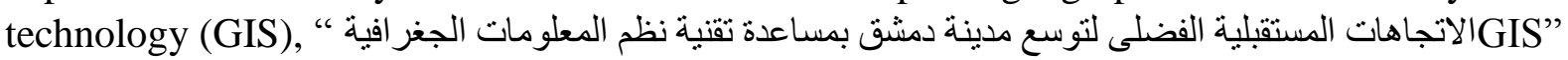
Planning and Environment College of Architecture Engineering - Damascus University of Engineering Sciences, volume 25 Issue No. 1, 2009 [translated from Arabic]

[10]Yass, Bushraabdulrahim Research" The Role of Investment Laws in the Residential Production” study area-Sulaimaniyah province - “" دور قو انين الاستثمار في الانتاج السكني Journal of Planner and Development Issue 29 October 2014- Center of Urban and Regional Planning for Post Graduated Studies - University of Baghdad- ISSN: 1996- 983X [translated from Arabic]

[11]Yass,BushraAbdulrahim, Research "The Sustainable Environmental Management for the city: Art \& Policy, case study Sulaimania City-Kanda SwraArea" Baghdad university , Center of Urban and Regional Planning for Post Graduated Studies-Journal of the Planner and development, Issue 32 November ISSN:1996-983X, 2015

[12] - Mc.Aslam, Patrick, "Positive Planning Law in Syria", International Urban Planning Legal Expert in Action Plan 9 of the Municipal Administration Modernization MAM, Project during a mission to Syria between 21 August and 11 September, 2008.

[13]Abdeen, Muhammad Yassar, and Al masri, Emad " Developmental Thinking in EbinKhaldoon Introduction” “ "الفكر التنموي في مقدمة ابن خلدون" An Analytical comparative Study 
DOI : https://dx.doi.org/10.26808/rs.aj.i6v1.08

American Journal of Sustainable Cities and Society

Issue 6, Vol. 1 January- December 2017

Available online on http://www.rspublication.com/ajscs/ajsas.html ISSN $2319-7277$

for the Theoretical Trends Explanatory of the urban development Process and the study of the evolution of development index with the Time, Damascus University, Journal of Engineering Sciences- volume 25 - first issue - Planning and Environment Department - Faculty of Architecture Engineering - University of Damascus - 2009 [translated from Arabic]

[14]Metcalfe, V. and S. Haysom, with E. Martin (2012) Sanctuary in the City: Urban Displacement and Vulnerability in Kabul, HPG Working Paper. London: ODI. 